This item was submitted to Loughborough's Research Repository by the author.

Items in Figshare are protected by copyright, with all rights reserved, unless otherwise indicated.

\title{
Evaluating the impact of academic liaison librarians on their user community: a review and case study
}

PLEASE CITE THE PUBLISHED VERSION

http://dx.doi.org/10.1080/13614533.2011.539096

PUBLISHER

(C) Routledge (Taylor \& Francis)

VERSION

AM (Accepted Manuscript)

LICENCE

CC BY-NC-ND 4.0

\section{REPOSITORY RECORD}

Cooke, Louise, Michael Norris, Nial Busby, Thomas Page, Ginny Franklin, Elizabeth A. Gadd, and Helen Young. 2019. "Evaluating the Impact of Academic Liaison Librarians on Their User Community: A Review and Case Study". figshare. https://hdl.handle.net/2134/8255. 
This item was submitted to Loughborough's Institutional Repository (https://dspace.lboro.ac.uk/) by the author and is made available under the following Creative Commons Licence conditions.

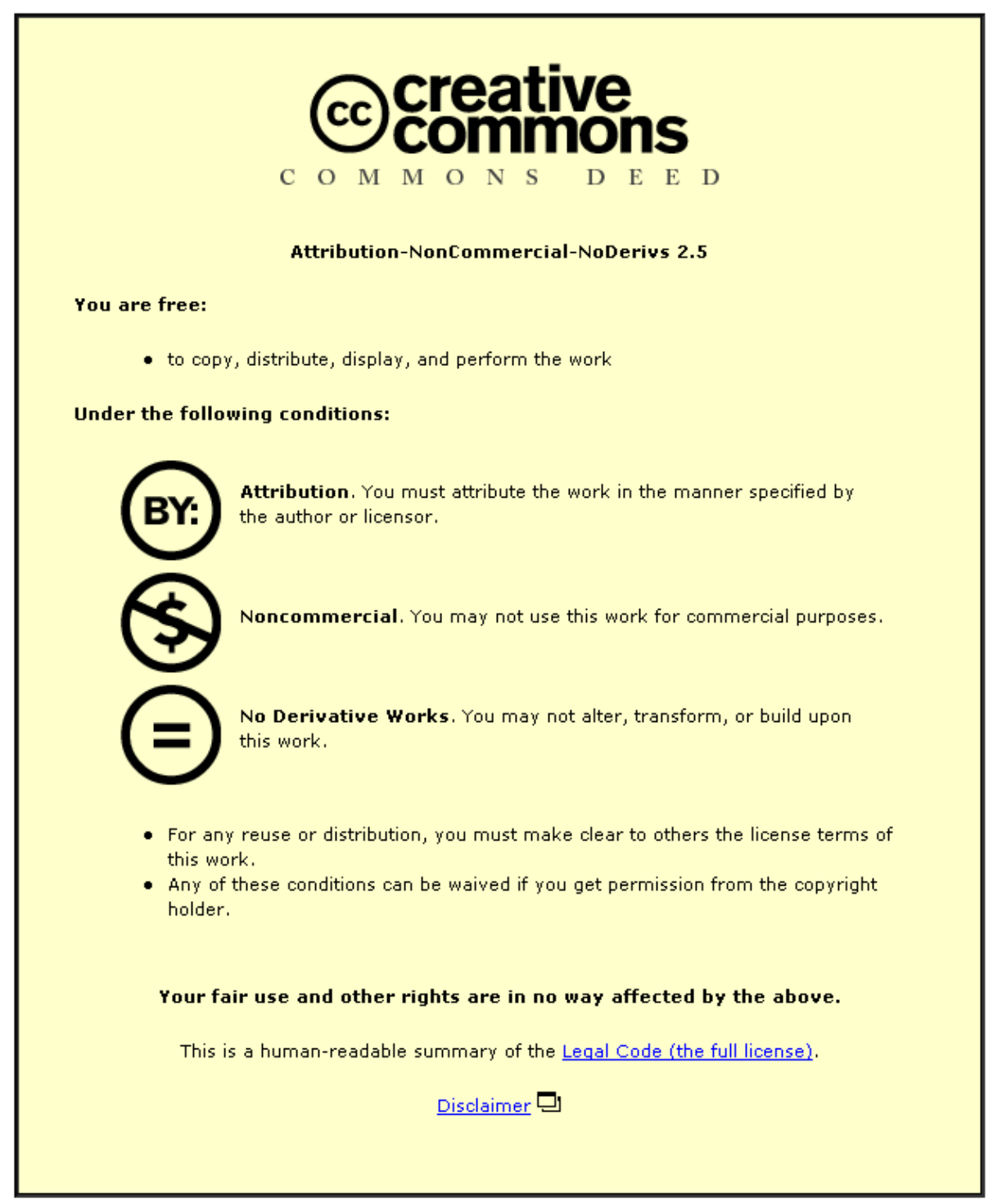

For the full text of this licence, please go to: http://creativecommons.org/licenses/by-nc-nd/2.5/ 


\section{Evaluating the Impact of Academic Liaison Librarians on their User Community - a Review and Case Study}

Louise Cooke $^{1 \mathrm{a}}$, Michael Norris ${ }^{\mathrm{a}}$, Nial Busby ${ }^{\mathrm{a}}$, Thomas Page ${ }^{\mathrm{a}}$, Ginny Franklin ${ }^{\mathrm{b}}$, Elizabeth Gadd ${ }^{\mathrm{b}}$, and Helen Young

${ }^{a}$ Department of Information Science, Loughborough University, Loughborough, LE11 3TU, UK

${ }^{b}$ Loughborough University Library, Loughborough University, Loughborough, LE11 3TU, UK

\footnotetext{
${ }^{1}$ Corresponding Author. Email: l.cooke@lboro.ac.uk.
} 


\section{Author Information}

Nial Busby BA is an MA student in the Dept. of Information Science at Loughborough University. He is also employed as Senior Library and Information Assistant at Bilborough College, Nottingham.

Louise Cooke BA CLTHE MA PhD MCLIP FHEA is Senior Lecturer in Information and Knowledge Management in the Dept. of Information Science at Loughborough University. Ginny Franklin BA MA MCLIP AHEA is Academic Librarian (Science Team) in the University Library at Loughborough University.

Elizabeth Gadd, BA MSc MCLIP FHEA is Academic Services Manager (Engineering) in the University Library at Loughborough University.

Michael Norris BA PhD is Research Associate in the Dept. of Information Science at Loughborough University.

Thomas Page BA MA is an MSc student in the Dept. of Information Science at Loughborough University. He is also employed as an Information Assistant in the Clifton Campus Library at Nottingham Trent University.

Helen Young BA MA MCLIP is Academic Librarian (Social Sciences and Humanities Team) in the University Library at Loughborough University. 


\begin{abstract}
The paper presents the findings of a small-scale study undertaken at a UK university. The purpose of the research was to investigate the perceived impact and value of the Academic Library Liaison service at the university. This was considered to be a critical issue of concern, in the light of drivers threatening the UK higher education library sector to de-professionalise - or worse, remove - such services. A mixed methods approach was adopted, combining an online questionnaire disseminated to academic staff, resulting in 29 responses from three academic departments, and in-depth interviews with eight members of academic staff. The results indicate that although academic staff do value the service provided by Academic Liaison Librarians (ALLs), there is scope to increase awareness of the range of services on offer. The study also demonstrates that academic staff prioritise the contribution that ALLs can make through the possession of in-depth subject knowledge, IT skills and well-developed communication skills, and through the provision of advice on copyright matters and assistance with institutional repositories. This holds implications for curriculum design on the part of LIS educators.
\end{abstract}

\title{
Keywords
}

Academic librarianship; Impact; User community; Evaluation; Liaison librarians; Subject librarians; University libraries

\section{Introduction}

The higher education context in the UK has been subject to rapid and sweeping change in recent years, and much of this change has impacted directly on the role and function of academic libraries. The increasing ubiquity of electronic resources has extended the library beyond its four walls (Brophy Libraries Without Walls); meanwhile, a renewed user focus, greater emphasis on the need for advocacy, the empowerment of the para-professional role, technological developments, and ever greater pressure on library budgets have all held implications for the ways in which the academic library functions, and have often resulted in redefined roles for key library staff. In particular, the traditional role of the 'Subject Librarian’ or ‘Faculty Librarian’ has shifted from one with an emphasis on knowledge and expertise of the resources of a particular subject domain, to a role that prioritises making connections with people and that promotes the work of the library to its potential users. This is reflected in changing nomenclature, with titles such as 'Academic Liaison Librarian², (ALL) finding favour. Corrall (27) highlights this change by noting that:

\footnotetext{
${ }^{2}$ This is the title that will be used primarily throughout this paper.
} 
The term ‘liaison librarian' or 'academic liaison librarian' has been chosen by many institutions to flag a shift in focus from looking after collections in a designated subject area to liaising with users from a named academic unit.

However, this change in function has rarely been accompanied by training that recognises the importance of this function and prepares librarians for the demands of this role. So, how effective are Academic Liaison Librarians (ALLs) in making these connections with their user communities?

This paper presents the initial findings of a pilot project undertaken at a UK University to investigate this question, and to determine the most appropriate focus and methods for further research in the area. The research team involved collaboration between library practitioners from the University Library, and academic staff and Masters students from the University’s Department of Information Science ${ }^{3}$. A recent survey carried out by library personnel of the information needs of research centres at the University had found that awareness amongst the centres' staff of academic librarians, and the services that they offer, was low (Lund et al. 11). This finding is set within a national context of 'deprofessionalisation' of library posts (“Cilip comes out fighting” 2) and in which at least two UK universities have threatened to withdraw all professional subject librarian posts (“Anger at threats to jobs” 2). At the same time, recent research suggests that economic recession and currency fluctuations have meant that most academic libraries are being forced to find ways of reducing staffing costs (Hutchings n.pag.). In such a context, an evidence-based analysis of the value and impact of such staff on their user community was deemed to be of critical importance.

The research was intended to answer two questions in particular in order to meet its overall aim of exploring the impact of academic librarians on their user communities:

\footnotetext{
${ }^{3}$ Project Team members involved in design of the study and the survey instruments included those from the University Library, the Corresponding Author, and the Research Associate (Norris). The field work and data analysis were carried out by the Research Associate, whilst the Postgraduate students contributed significantly to the literature review.
} 
- How typical is the finding (cited above) of low awareness amongst academic staff of the services offered by academic librarians for other user communities?

- How can academic librarians improve their visibility and increase their impact on their user community?

These questions led to some specific objectives:

- To evaluate the awareness and perceptions among academic staff of their own subject librarians;

- To investigate the areas of expertise and specific services of academic librarians that are of most perceived use and value to their user community;

- To identify how academic librarians can increase their impact on their user community.

Given the professional context with regard to the de-skilling and devaluation of the work of subject librarians, it is anticipated that the findings from this study will be of interest and value to the wider academic and professional community. In addition to the contribution to knowledge made by the findings, we see this project as a valuable example of the potential offered by collaboration that brings together Library and Information Science (LIS) academics, practitioners and students in the research process.

\section{Background and context}

\section{Role of the ALL}

The model of employing 'Subject Librarians', with responsibility for a particular academic subject or subjects, was first apparent in UK universities in the early $20^{\text {th }}$ Century (Feetham 3). Having steadily gained prominence, this role endures in the early $21^{\text {st }}$ century and has developed to encompass tasks such as the selection and management of electronic and hard copy resources; reference work; liaison with academic departments; and information skills training. Increasingly given the title of 'Academic Liaison Librarian', the emphasis of the 
role, as discussed previously, has shifted towards the importance of developing a working relationship with the academic departments and student users that the post is intended to support and therefore now requires a proactive approach to engaging with users (Rodwell and Fairbairn 117; Gibson and Luxton 43-44; Pinfield 34; Corrall 15-39).

This new role does not, however, represent a radical departure from earlier models: according to Rodwell and Fairbairn (117) it can be seen as a natural evolution from the more traditional subject specialist or special collection role. McAbee and Graham (24-25) highlight the need for the subject-specialist librarian's role to evolve into what is now recognised as that of the ALL, with an emphasis on improved liaison if the academic library service is to meet clients' needs effectively. This concurs with Rodwell and Fairbairn’s suggestion that the evolution towards a liaison model intensifies the 'go-between' role between faculty and library, to the extent that ALLs become an 'equal professional partner in...research, teaching and learning functions’ (Rodwell and Fairburn 120). Moreover, the role is, of course, not a homogenous phenomenon - the diversity of mission of different higher education institutions within the UK and beyond (Brophy “The policy framework” 1415), and subsequent diversity of user needs, has resulted in a 'fluidity in the role description' for ALLs in different universities (Crawford 34).

At the same time, rapid developments in technology have led to a move away from an emphasis on the role of libraries in managing holdings to one of providing access to information. As Feetham (11) puts it, 'The role of the librarian has consequently changed from custodian of a physical collection to that of supporting the networked information user'. This trend is surely set to continue apace, as the migration of the journal literature from print to electronic format is followed by the e-book and the Google Book Search project (Gibbons xiii-xv), and increasing amounts of scholarly comment and research are to be found in institutional repositories and other online databases. Meanwhile, with the advent of services 
such as ‘Ask a Librarian’, Dilevko (232) discusses the future of academic reference services in terms of the model of a 'digital reference call centre'.

\section{De-professionalisation}

However, whilst the role of Academic Liaison Librarian has generally been accepted to be one that requires the skills and knowledge of a qualified professional librarian, it has also been argued that many of the functions previously seen as intrinsic to the role can be devolved to central functional and paraprofessional staff (Brophy The Academic Library 100; Biddiscombe 228). Other functions have become dependent on the input of IT services, as the onward march of technology continues to shape library services. Simultaneously, these developments in technology have contributed to an increase in end-user empowerment, whereby access to the Web has enabled users to satisfy most of their information needs without the intermediation of an academic librarian (Biddiscombe 230). Indeed, in two UK universities, the post of Academic Liaison Librarian has been withdrawn altogether on the grounds that 'students can find the information they need on the internet' (Curtis n.pag.) and other such posts elsewhere have been threatened with redundancy (“Cilip comes out fighting”; “Anger at threats to jobs”). Rodwell and Fairbairn comment that in the face of 'the pervasiveness of digital technology, university libraries are attempting to redefine their core activities to maintain their relevance' (116). One of the major consequences of the shift to digital resources is what Biddiscombe (228) describes as 'the empowerment of the end user', echoing Sturges' notion of a 'process of disintermediation’:

As information became available at computer terminals linked by modems to remote databases, the importance of the library as a place where information was stored was diminished. The idea was that a search for information could as easily take place in a researcher's office as in a library, and could as easily be done by the researcher as by the librarian.

(Sturges 62)

\section{The struggle for visibility}

Thus it can be seen that in recent years, academic libraries and ALLs have faced some serious challenges. Not only have budgets come under threat from a combination of a difficult 
external economic and financial climate ${ }^{4}$ and changes in the purchasing power of journal budgets as a result of unfavourable currency changes and publishers' 'bundled' purchase agreements, there is also an ever-growing range of resources available for acquisition. At the same time, the 'visibility' of the library has become less tangible as an increasing number of services and resources are provided ‘virtually’ via the office or laboratory desktop. The 2007 Research Information Network and Consortium of Research Libraries (RIN/CRL) report evidences that electronic resource availability has resulted in greater emphasis on remote research with consequently fewer research visits to the physical library (RIN/CRL19-20).

In an era of financial cutbacks, such developments arguably represent a considerable threat to the professional librarian with a decline in the overt visibility and apparent value of their presence and role. However, Biddiscombe suggests that, as traditional roles disappear or are transferred to paraprofessional staff, 'there should be opportunities for redeploying librarians into expanding areas of learning support' (231). This is particularly true with regard to support for the development of key information literacy (IL) skills, essential to the identification, retrieval, selection and evaluation of electronic sources. However, it cannot be ignored that recognition of the role that academic librarians have to play here is dependent on being able to demonstrate the value and impact of such a role.

\section{Relationships between academic staff and liaison librarians}

Demonstrating this value and impact is not an easy task. It has been suggested that some academics still view ALLs as 'subordinates, check-out chicks seeking self-aggrandisement' (Doskatsch 119), whilst librarians state the case for a 'pro-active partnership' between both parties interacting as ‘equals’ (Neal et al. 408). In an Australian context, the Ross Report predicted 'close and continuing collaboration' between academics and ALLs in the realm of teaching and integration of IL into the curriculum (qutd. in Doskatsch 113): however, this is

\footnotetext{
${ }^{4}$ English universities are reported to be facing budget cuts of at least $£ 449$ million, leading to a reduction of 6,000 in student places in the academic year 2010-2011. (Richardson, 2010)
} 
rarely achieved for a variety of reasons. The literature suggests a range of perceptions held by academic staff which might affect the development of collaborative practice, including:

- The multiplicity of titles and roles for the ALL makes it difficult for academic staff to understand what services the ALL provides (Rodwell and Fairbairn 118; Holbrook 269);

- The ambivalence of some academic staff toward closer library liaison - the facultylibrary relationship has been characterised as having an 'asymmetrical disconnection' (Christiansen et al. 118), an impediment to full liaison which only library staff view as problematic (Doskatsch 113);

- In tandem with the above, there can exist a culture conflict between ALLs who see it as their mission to reach out to users, whereas 'faculty culture is generally...isolated and proprietary’ (Christiansen et al. 118);

- Infrequent interaction between library and academic staff revolving primarily around 'functional' matters, with ALLs viewed as reactive service providers (McGuinness 249), who are 'non-expert' in faculty fields of expertise (Christiansen 118);

- Academic staff may also hold the perception that it is the function of librarians to organise and facilitate access to knowledge, whilst they control its production and dissemination (Christiansen 119); and

- Academic staff are generally 'physically and temporally separated' from the library (Christiansen 118).

This latter factor is not new: Holbrook (273-274) addressed it in relation to subject librarians in 1984, whilst Kotter (296) suggested in 1999 that a faculty member may have 'minimal substantive contact' with the library due to various behavioural and spatial impediments. 
However, the failure of effective liaison cannot wholly be attributed to academic staff. Inadequate interpersonal or pedagogical skills on the part of some ALLs may, of course, impede effective academic collaboration. Further, it would be erroneous to assert that all LIS professionals believe improved faculty-library relations to be important, with some dismissing it as 'chimera' (Kotter 295). Effective liaison requires changes in the role of the ALL to be proactively communicated to the academic community (Gannon-Leary 12-13). As has already been proposed, the change in role is not radical and aspects of the 'traditional' subject librarian remain in the management of reading lists and highlighting of relevant new resources: however, guidance on digitisation and copyright issues (among many others) may also now be provided (Neal et al. 8). Meanwhile, membership of and input into faculty committees improve visibility and aid the process of aligning often disparate agenda (Neal et al. 6-7). Such activities help to build mutual trust and form a good basis for an academic-ALL relationship, giving the library a 'face’ and opening possibilities for further and deeper cooperation.

\section{The "Google Generation" and information literacy}

According to Cummings, the current generation of university students is unique in terms of its implications for the academic library:

Unlike previous generations who came to the library as their first stop for papers and projects, the Millennials have alternative resources at their fingertips which are forcing libraries to prove, more than ever, that their research needs can be better met through the library, whether online or in person.

(Cummings 286)

Similarly, Prensky’s well recognised categorisation of the younger generation as 'digital natives’ who have grown up with new ICTs as an integral component of everyday life (Prensky 1-2), and who have wholly new ways of thinking about and interacting with technology, carries with it serious implications in terms of the relevance of current approaches to academic library services. Selwyn (365) speaks of 'distinct technological characteristics that set them apart from their elders', while Burhanna et al. (523) describe 
them as 'more technologically savvy and perhaps more technologically dependent than any preceding generation'. As a result of this familiarity with technology it is often perceived that students of this generation 'are confident in their search abilities...believe they can find what they need for course work and research on their own' (Mi and Nesta 417), thus driving the process of disintermediation discussed above.

Nevertheless, a number of researchers urge caution in our interpretation of the extent of these changes. For example, Aubele et al (5) suggest that there is 'a palpable sense among academic librarians that Millenials arrive ill-prepared and, in some cases, incapable of conducting even the most rudimentary scholarly research'. This view is supported by McKnight who is reported as stating that 'digital natives' 'often lack deep information literacy or understanding of the crucial issues of plagiarism, copyright and accessibility compliance’ (Reisz 16). The response from the library to the Google generation may, therefore, be pivotal. Cummings (286) proposes that librarians need to 'physically "move out of” or "leave” the building and take...instruction and reference services across campus’ suggesting the imperative for academic librarians to engage proactively with the user if they are to ensure the continued relevance of their role.

In addition, the users that are served by academic librarians - whether virtually or in person - have changed in ways that go beyond technological capability and familiarity. As a consequence of the widening participation agenda, student populations in the UK are now far more diverse and heterogeneous than was the case in previous era. With a former policy goal 'to ensure that all those with the potential to benefit from higher education have the opportunity to do so whatever their background and whenever they need it' (HEFCE 5) and a previous government target of 50\% of 18 -30 year olds having some experience of higher education by 2010 (Lewis 204-205), recent decades have seen a significant change in the make-up of the student population. Students may enter university with variable prior 
educational background and achievement, and familiarity with the use of libraries and academic sources cannot be assumed. As a result of recognition of these issues, IL work with students now forms a significant proportion of the day-to-day engagement of the ALL (Doskatsch 113-115), thereby further extending the teaching element of the role and the potential for ALLs to collaborate with academic staff on the integration of IL into the curriculum.

\section{Measuring impact - the Holy Grail}

The previous discussion has hinted at a strong imperative for ALLs to be able to measure and demonstrate their impact on and value to their user communities, in order to ensure continued institutional support for their activities. However, the difficulties inherent in studying impact are widely acknowledged (Brophy “The development of a model” 43-49; Poll and Payne 550-551; Lindauer 546-547). Previous attempts to measure the 'impact' of the ALL have tended towards the use of Performance Indicators and ‘measurement of activity’ rather than evaluation of the difference a service can make to its users. There are some notable exceptions: for example, Markless and Streatfield have undertaken a considerable body of work on evaluation of impact, which they define as 'the difference made to individuals or communities by a service’ (Markless and Streatfield 5). Brophy, who has also undertaken extensive work in the area of impact assessment, offers a similar definition that also focuses on the 'effect of a service, product or event on an individual or group' and seeks to remedy any confusion between 'impact' and 'outcomes' by suggesting that the latter should signify immediate effects, while 'impact' denotes the longer term (Brophy “The development of a model” 44). Overall, however, much of the evaluation work carried out to date in an academic library context has tended to focus on specific library activities or services, rather than the difficult task of assessing the 'added value' from a particular service role, such as academic liaison. This is, of course, notoriously difficult to measure in the absence of any 
'before and after' benchmarks, or any clear boundaries to the activities or end products impacted by the role. As a result, impact studies are limited to a focus on user perceptions of a service, or, at best, will 'inevitably provide a snapshot of what is happening at a particular point in time' (Everest and Payne 21), rather than tracking changed behaviours and the development of new skills, as proposed by Brophy ("The development of a model” 44).

Within a UK context few studies have therefore sought to address the specific impact of ALLs. In the US some work has been undertaken in this respect, albeit still focussing on user perceptions. For example, Yang (124) examines faculty perceptions of Liaison Librarians, asserting that 'No single article has yet given a comprehensive assessment of faculty members’ perception of a liaison program’. While findings from this study suggest that 'faculty are willing to take advantage of services the library may offer', Yang (128) warns that 'Libraries implementing a liaison program...need to be cognizant of the faculty’s changing needs and perceptions of the library'. Glynn and Wu undertook a longitudinal study that aimed to evaluate changes to the library liaison landscape, comparing results of a survey with earlier findings. Their recommendations centre on the need for good communication through 'effective liaison channels’ and ‘the importance of the human touch’ (Glynn and Wu 128). In less recent work, Ryans, Suresh and Zhang report a positive response to liaison activities, but also draw attention to a need for improved communication as some respondents were ‘only vaguely aware’ of the services on offer (Ryans, Suresh and Zhang 20).

\section{Methods}

Two approaches were used in the research. The first was a questionnaire survey ${ }^{5}$ and the second involved a follow up interview with those survey respondents who volunteered. Three university departments were approached to take part in the survey: English and Drama; Civil and Building Engineering; and the Department of Materials. These departments were selected

\footnotetext{
${ }^{5}$ A copy of the blank questionnaire is available on request from the Corresponding Author.
} 
primarily on the basis of purposive sampling, as they represented each of the Faculties at the University. Each of the departments have designated ALLs who provide teaching support relating to the effective use of library resources and study skills, to undergraduate and post graduate students, as well as being involved in supporting the research effort of the departments by ensuring they have access to the appropriate information resources and the relevant skills to exploit them. Their Heads of Department or Library Liaison Officers $(\mathrm{LLOs})^{6}$ circulated, by email, a request to academics to complete the online questionnaire. This method of circulation 'distanced' the survey dissemination from the library itself, to encourage openness in feedback. Respondents were also assured anonymity in any reporting of findings. They were also asked if they would be prepared to be interviewed.

The survey principally sought to establish whether academics were aware they had an ALL, how their ALL had helped them, the key skills they thought their ALL should possess, the services they should provide and what library services they had used over the last twelve months. Semi-structured interviews were held with academics from all three of the participating departments to assess their views of the services provided by ALLs. All interviews were carried out by a Research Associate who is not employed within the Library: this was intended to increase the objectivity, candidness and honesty of responses, and to avoid placing interviewees in a position in which they felt compromised. The terms of the interviews were that the specific content of an individual's interview should remain confidential to the project team, whilst anonymised themes could be reported more widely.

\section{Results}

For the purposes of conciseness, the findings presented in this paper represent a selection from the total study findings. These have been selected on the basis of perceived relevance and interest to the potential readership of this journal.

\footnotetext{
${ }^{6}$ A Library Liaison Officer is a named member of academic staff who is nominated to be the focal point of contact between their academic department and the University Library.
} 


\section{Survey findings}

Twenty nine responses to the questionnaire were received; eight from English and Drama, ten from Civil and Building Engineering and eleven from the Department of Materials. The total number of potential respondents was estimated at $107^{7}$ giving an overall response rate of about 27\%. Of these respondents, eight volunteered to be interviewed; five from English and Drama, two from Civil and Building Engineering and one from the Department of Materials. Of the 29 respondents, 25 knew that they had an ALL who liaised with their department. Twenty two respondents could name their $\mathrm{ALL}^{8}$; of the seven that could not, four were from Materials (they did not know they had one), two from English and Drama and one from Civil \& Building Engineering.

Table 1 shows a breakdown by department of the frequency of contact between academics and their ALL. Academic staff in the department of English and Drama appear to be the most active users of the academic liaison service, although the small sample size necessitates caution in the interpretation of such findings.

Table 1. Have you ever had any dealing with an ALL here at this University?

\begin{tabular}{|c|c|c|c|c|c|}
\hline & Respo & & & & \\
\hline Department & Never & Once in a while & Frequently & Don’t know & Total \\
\hline English \& Drama & - & 3 & 5 & - & 8 \\
\hline Civil \& Building & 1 & 6 & 3 & - & 10 \\
\hline Materials & - & 4 & 3 & - & 7 \\
\hline Total & 1 & 13 & 11 & - & 25 \\
\hline
\end{tabular}

Note: the 4 respondents from Materials who did not know their ALL did not respond

Academics were asked for examples of how ALLs had helped them. The four respondents from Materials who did not know their ALL did not respond along with another

\footnotetext{
${ }^{7}$ The figure is an estimate based on the number of academics listed for each department on their respective web pages.

${ }^{8}$ One respondent gave the name of their Research Centre Librarian but considered them as a 'viable substitute'.
} 
respondent from Civil and Building Engineering. The remaining 24 respondents gave examples: these ranged from personal training and advice (8), group training events (6), sourcing various resources (6) and literature searches (3) to maintaining reading lists (3).

The respondents were asked to select what key skills or traits they thought it most important that an ALL should possess; they were limited to making a selection of three from a choice of ten characteristics. Between them the respondents made 106 selections $^{9}$. Table 2 shows these results.

Table 2. Skills or traits that academics $(n=29)$ thought ALLs should have

\begin{tabular}{|l|l|c|}
\hline Characteristic & Number & $\begin{array}{c}\text { Percentage of respondents } \\
\text { selecting attribute }\end{array}$ \\
\hline Subject knowledge & 27 & 93.10 \\
\hline Ability to keep up to date & 23 & 79.31 \\
\hline IT skills & 15 & 51.72 \\
\hline Verbal communication skills & 13 & 44.83 \\
\hline Pedagogic knowledge & 9 & 31.03 \\
\hline Flexibility & 8 & 27.59 \\
\hline Sense of humour & 4 & 13.79 \\
\hline Presentation skills & 3 & 10.34 \\
\hline Written communication skills & 3 & 10.34 \\
\hline Diplomacy & 1 & 3.45 \\
\hline
\end{tabular}

Respondents were also asked to select, from 20 options, the services they thought ALLs should be able to help them with; 187 selections were made. Respondents could select all those that applied. Table 3 shows these selections both by their overall number and percentage.

\footnotetext{
${ }^{9}$ Some respondents selected more than three characteristics.
} 
Table 3. The services that ALLs should be able to help with

\begin{tabular}{|l|l|l|}
\cline { 3 - 3 } \multicolumn{2}{l|}{} & $\begin{array}{l}\text { From 29 } \\
\text { Academics } \\
\text { (n=29) }\end{array}$ \\
\hline Services & No & $\%$ \\
\hline Giving copyright advice & 23 & 79.31 \\
\hline Putting content in the Institutional repository & 19 & 65.52 \\
\hline Finding an impact factor of a journal & 18 & 62.07 \\
\hline Doing a literature search & 17 & 58.62 \\
\hline Teaching students study skills & 17 & 58.62 \\
\hline Seeking copyright permission for you & 16 & 55.17 \\
\hline Teaching students about plagiarism & 16 & 55.17 \\
\hline Doing citation analysis & 14 & 48.78 \\
\hline Using RSS feeds & 10 & 34.48 \\
\hline Delivering interlibrary loans and photocopies to your desktop & 9 & 31.03 \\
\hline Using Learn ${ }^{10}$ & 8 & 27.59 \\
\hline Searching Google & 6 & 20.70 \\
\hline Working on a research project & 4 & 13.79 \\
\hline Helping with assessment (for a module you teach) & 2 & 6.90 \\
\hline Photocopying books and journals for you & 2 & 6.90 \\
\hline Creating a Wiki & 2 & 6.90 \\
\hline Setting up a personal homepage & 0 & 0 \\
\hline Designing a module & 0.45 \\
\hline Marking assignments (for a module you teach) & 0 \\
\hline Other(s) see Q9 & 9 \\
\hline
\end{tabular}

Note: Total no. of respondents to this question $n=29$

Question 9 invited respondents to suggest other services not mentioned in Question 8 and three academics gave other choices. It was interesting to note that the majority of these comments cited activities that are already provided by the academic liaison service (e.g.

\footnotetext{
${ }^{10}$ Learn is the name of the institution's Virtual Learning Environment.
} 
arranging free trials of new resources), suggesting that there is a lack of awareness of services on offer.

Question 12 invited respondents to select from 16 options, the services they had used over the last twelve months; 196 selections were made. Table 4 shows these selections both by their overall number and percentage.

Table 4. What services have been used by academics in the last twelve months

\begin{tabular}{|l|l|l|}
\cline { 3 - 3 } \multicolumn{2}{l|}{} & \multicolumn{2}{l|}{$\begin{array}{l}\text { From } 29 \\
\text { Academics } \\
\text { (n = 29) }\end{array}$} \\
\hline Services & No & $\%$ \\
\hline Read an e-journal provided by the Library & 26 & 89.66 \\
\hline Used MetaLib ${ }^{11}$ & 23 & 79.31 \\
\hline Used a database provided by the library & 23 & 79.31 \\
\hline Asked a question at a Library enquiry desk & 19 & 65.51 \\
\hline Recommended a book for purchase & 18 & 62.07 \\
\hline Ordered an Inter-library loan & 15 & 51.72 \\
\hline Had a one-to-one meeting with an Academic Librarian & 11 & 37.93 \\
\hline Put content in the Institutional Repository & 11 & 37.93 \\
\hline Used RefWorks & 10 & 34.48 \\
\hline Phoned the library to ask a question & 9 & 31.03 \\
\hline Asked for Library training for your students & 8 & 27.59 \\
\hline Recommended a new journal title for purchase & 6 & 20.69 \\
\hline Arranged study skills training for your students & 6 & 20.69 \\
\hline Invited an Academic Librarian to contribute teaching to a module & 6 & 20.69 \\
\hline Used the Ask-a-Librarian email enquiry service & 3 & 10.34 \\
\hline Recommended a database for purchase & 2 & 6.89 \\
\hline
\end{tabular}

Academics were asked what other comments they had regarding the role of ALLs seventeen of the 29 respondents to the survey offered a comment here. These comments were

\footnotetext{
${ }^{11}$ Metalib is a federated search service across the range of databases to which the library subscribes.
} 
overwhelmingly positive, applauding the contribution that ALLs make to the effective teaching and learning environment in their department and the support that they provide to academics in their role as lecturers and researchers, as well as to the work of their students. Strong feelings were expressed with regard to the importance of retaining the role. Such comments are typified in the following example:

They are a fantastic resource and support to the department, and their subject specialism and interest in and commitment to the department adds crucially to the experience of both staff and students. The research of both staff and students would suffer if they were not to continue to be able to offer their specialist knowledge to us.

\section{Interview findings}

Seven of the eight respondents who agreed were interviewed, the other being unavailable at the time that the interviews were scheduled. Four of these respondents were from English and Drama, two from Civil and Building Engineering and one from the Materials department. The opening question was concerned with assessing the types of contact that academics had with their ALLs. In the majority of cases contact was characterised by academics co-opting them into supporting their teaching of modules where library skills were an important part of the content, either as a general introduction or where students were involved in Research Methods courses leading to the writing of dissertations. ALLs delivered module content themselves and made this subsequently available to students electronically. Other contacts were more extensive; one interviewee who was a Library Liaison Officer (LLO) had routine contact with the department's ALL through library user committee meetings, email correspondence and interventions from colleagues who sought local advice on library matters. The LLO was also involved in annual assessments of serial holdings and how library budgets may be spent to greatest effect. Apart from these more formal interventions, interviewees contacted their ALL to obtain particular items, discuss the acquisition or discontinuation of databases or their trial and evaluation and, as an example of a more routine task, to expedite requests into the short loan collection. One interviewee noted the extensive support that their ALL gave on using the University's Virtual Learning Environment (VLE). 
Other notable interventions were help with depositing items in the University's institutional repository and in the use of databases to find, for example, patent information and testing standards.

Interviewees were asked if their experience of the services offered and delivered by ALLs was positive or otherwise; this was met with a generally positive response. There were a range of observations, however; one interviewee had limited awareness of the identity of their ALL and this tempered their appreciation of what could be offered by them. Not surprisingly, perhaps, it appeared that the greater the involvement that the academic had with their ALL, the greater the level of their appreciation of the services and expertise that they could offer. Generally when interviewees visited the library it was for routine matters that could only be undertaken within the library premises. Otherwise the electronic resources made available by the library met their information needs and where there were queries these were usually resolved by telephone or email.

All new academics in the university are offered the opportunity to have an introduction to the library and its services. In an attempt to elicit views on whether this was useful or not interviewees were asked if they had used this service. In some cases they had not and had been comfortable to explore what the library had to offer on their own, but on the other hand some of the interviewees had found it a positive experience. In some cases because of long service this was either not recalled or its details were too distant. There was a perception in one case that perhaps the offer of an introduction to the library was made a little too early when new academics were still finding their feet and that perhaps a grouped activity for recent recruits might be a less formal introduction.

Interviewees were asked which electronic services they found most useful and if they knew how these resources were selected. Reponses ranged from a limited use of electronic resources to an extensive and very certain knowledge of what they used and what the 
resources had to offer. It appeared clear that comparatively recent database acquisitions for the English and Drama department had made a significant impact on the way academics accessed documents; formerly they may have made interlibrary loan requests or had to visit other libraries to access the material needed. Early English Books Online, Eighteenth Century Collections Online and Literature Online as well as access to journals through Project Muse and JSTOR were cited. It was evident that in general the department were aware of how resources were acquired and were in close contact with their ALLs. They viewed their interaction as a partnership between themselves, the ALLs, the library and its resources. This is reinforced by the fact that their ALLs appear as staff members on the department's home page. Responses from the other departments indicated a more distant approach where they were aware of the resources they needed, be it Construction Information Service (CIS) or the American Society of Heating, Refrigerating and Air-Conditioning Engineers (ASHRAE), and the information they held. Heavy use was made of journals, standards, reports and guidance documents. However, unless they had a particular resource in mind often they cited their LLO as the way they became aware of or influenced decision making or choices in this area: alternatively, they were unclear how these resources were managed. It was noticeable that in one case there was limited knowledge about which journals and resources were available in electronic form and how these might be accessed.

How the ALL might support the research and teaching process was met with a range of responses. In one case the interviewee was cautious about how an ALL could help them in their research and was protective of the process and how they went about it. However, they were enthusiastic in the support the ALL gave in the lectures associated with library services. On the other hand one interviewee had a very clear view of what, in part at least, the role of the ALL should be: 
actions to getting access in place and then providing whatever necessary training either by

doing it themselves or getting the people in who have sold us the product.

And on the teaching processes the interviewee thought that in making students aware of plagiarism the ALL provides:

....all the details. Whereas I sketch in what's going to happen, [the librarian] puts in the chapter and verse. The students get a very different impression, the students think well this is the whole university it's not just English and Drama. It is the way [the University] runs and this makes them take it much more seriously.

One interviewee thought one of the most valuable ways that an ALL can help in their research was by offering briefings for newly recruited Research Associates on the resources that the library could offer to them, closely related to the subject they were to research. This was echoed by another interviewee but with their research students in mind. They perceived such briefings to have a twofold benefit; firstly to brief the research students who, on their return from the library, would then go on to brief academic staff about resources hitherto unknown to them. Having support on some of the technical issues, like how to identify relevant discussion lists and getting signed up to them efficiently was a task one interviewee thought useful. Being able to support students on a one-to-one basis was a common theme as was the undoubted value ALLs provide by giving library information lectures. This eased the burden on lecturers but also introduced students to the library and ALLs as a source of further help and information. On a routine basis interviewees appreciated that short loan allocations were made and reading lists were catered for.

In a concluding ‘open’ question inviting interviewees to add any further thoughts on the subject of ALLs, respondents thought in general that some expertise in their subject and an understanding of how the subject was taught and researched was useful. This added credibility to the ALLs' standing and aided their perceived usefulness. Seeing ALLs in the department and building up a face-to-face relationship was seen as a key motivator for one relatively new academic, to engaging with ALLs and dispelling any thoughts that there might 
be a lack of subject expertise. One interviewee felt that the University was successful because it allowed, within the rules, each department to do things in its own way and having:

\begin{abstract}
... ALLs who have this sense of genuine connection to specific departments makes that happen, makes it possible in a way it wouldn't be if the librarians were being required to have a so called expertise across a much wider field, because they wouldn't have the depth of understanding that they do when they've got a smaller number of departments they relate to.
\end{abstract}

In the future, an interviewee noted the importance of the Research Excellence Framework (REF) and the need to assess citation counts, and the way this may be done. Further support for students was envisioned by one interviewee where VLE materials could be more integrated into the teaching process by ALLs providing a range of additional resources that students might access for their coursework assignments.

\title{
Discussion and implications of the project
}

In the current difficult financial climate, academic librarians can ill afford not to recognize and respond to changes in their external and organisational environment, and part of these changes imply ensuring that users are aware of the services that they are providing. Although the current study found little evidence of ALLs being under-valued - on the contrary, there were many testimonials to the value of the services that they offer - there was some evidence of lack of awareness of much of what they are able to do. This supports the call for a more proactive approach towards user engagement and demonstration of value on the part of ALLs identified within the literature (Rodwell and Fairbairn 117; Morgan 41-49; Gibson and Luxton 43-44; Pinfield 34; Corrall 15-39; Cummings 286).

Moreover, the study indicates that the knowledge, skills and services that appear to be most highly valued by users may not reflect those on which greatest emphasis is placed by those who are managing library services - or who are educating future LIS professionals. An interesting finding is that subject knowledge and keeping up-to-date in one's subject field are seen by academic staff as critically important attributes of an Academic Liaison Librarian, yet 
all too often ALLs may be assigned to an academic discipline area in which they do not possess prior knowledge (Pinfield 33). As noted above, the value placed by academic staff on the communication and IT skills of liaison librarians also carries with it implications for LIS education and the provision of effective opportunities for Continuing Professional Development. The primacy of copyright advice as a key service also has implications for the role of ALLs. Although this has long been seen as a domain that falls within the formal remit of university library services, there is often insufficient provision made for regular in-depth and continuing professional education and development in this arena, despite the fastchanging nature of the intellectual property rights environment.

Another important finding of the study is the impact of disciplinary culture on perceptions of the importance and value of ALLs. Although this finding might have been anticipated in the light of previous work by Webber (12-14) among others, it is noteworthy that this limited study involving only three academic departments found recognisable differences in use and appreciation of the academic liaison service: in particular, the department of English and Drama were clearly proactive users of the service and included their ALL as a member of their staff on the departmental web pages. On the other hand, in other departments, there was some evidence of Christiansen et al.’s (118) notion of the ‘isolated and proprietary’ faculty culture, with academic staff sometimes preferring to retain full control of their research activity in particular. Indeed some members of staff of the department of Materials were seemingly unaware of the existence of the ALL service. Such disciplinary differences merit further study, and potentially suggest different approaches towards academic liaison might be appropriate according to disciplinary area.

Of course, the limitations of this study need to be acknowledged and their impact recognised. Empirical work was restricted to three departments in a single case site; however, the authors believe that the departments are probably not untypical of other UK 
universities. A wider project to test the findings in a broader context would be useful. Possible bias of findings should also be taken into consideration: in essence, respondents and interviewees were self-selected and were therefore highly likely to reflect the views of proactive users of academic liaison library services. Research that better captures the views and opinions of non-users of liaison library services would be most apposite. Similarly, apparent differences in disciplinary cultures may, in reality, reflect the practices and approaches adopted by the ALLs themselves. Finally, this study has focused on academic staff as users of the liaison service: research that takes account of the views of the wider user population, and especially those of students, would be helpful. Thus, this study has identified a number of avenues for further work, as well as proving the reliability of the research instruments. There is scope for replication and extension of the work in other institutional contexts $^{12}$

\section{Conclusions}

This small study aimed to explore a number of concerns emanating from the current internal and external environment in which ALLs are working. In response to the original research questions and objectives, the findings indicate that, as far as this University Library is concerned:

- Academic staff place a high value on the service offered by their ALLs and understand the contribution that they have to offer to the learning experience of their students, and to their own research;

- However, there is a lack of full awareness of the services on offer, and ALLs need to do more to promote their own services;

\footnotetext{
${ }^{12}$ The researchers would be pleased to hear from anyone wishing to undertake such work and would be happy to offer assistance with the provision of the original data collection tools.
} 
- Recognition of the contribution and availability of academic liaison services, and take-up of the services, appears to differ significantly according to the specific discipline;

- In-depth and up-to-date subject knowledge is an attribute of ALLs that is highly prized by their academic staff user community, closely followed by the possession of well-developed communication and IT skills;

- In terms of services that ALLs provide, academic staff appear most to value assistance with copyright matters and institutional repositories.

The findings suggest that there is a need for ALLs to continue to develop mechanisms and media for promoting their services and for raising awareness among their user communities of what they have to offer, as well as continually to adapt according to changing user needs and priorities. For LIS educators, the findings indicate that more emphasis needs to be placed in the LIS curriculum on the skills of advocacy, communication and marketing of services. The findings of this study lend weight to the argument against further deprofessionalisation of the role, and demonstrate the continuing value and importance of the ALL service in the 'new learning environment' (Levy and Roberts).

\section{Acknowledgments}

The authors would like to thank the staff who participated in the survey and those who agreed to be interviewed. Thanks also go to Gary Brewerton the University Library's Systems Manager who helped in the design and hosting of the online questionnaire and the Faculty of Science who provided funding for the empirical work undertaken.

\section{References}

“Anger at threat to jobs of subject librarians at University of Wales, Bangor”. Library \& Information Update 4.3 (2005): 2. Print.

Aubele, Joseph, Susan Jackson and Lesley Farmer. “Technology Impact on Information Needs and Behaviours of the Academic Community.” The Human Side of Reference and Information Services in Academic Libraries: Adding Value in the Digital World. Ed. Lesley Farmer. Oxford: Chandos, 2007. 1-17. Print. 
Biddiscombe, Richard. "Learning Support Professionals: the Changing Role of Subject Specialists in UK Academic Libraries.” Program: Electronic Library and Information Systems 36. 4 (2002): 228-235. Print.

Brophy. Peter. The Academic Library. $2^{\text {nd }}$ ed. London: Facet, 2005. Print.

Brophy, Peter. “ The Policy Framework: a Critical Review.” Developing the New Learning Environment: the Changing Role of the Academic Librarian, Ed. Philippa Levy and Sue Roberts. London: Facet. 2005. 1-23. Print.

Brophy, Peter. "The Development of a Model for Assessing the Level of Impact of Information and Library Services.” Library and Information Research 29.93 (2005): 43-49. Web.

Brophy, Peter. Libraries Without Walls: Exploring Anytime, Anywhere Delivery of Library Services. Pt.7. London: Facet, 2008. Print.

Burhanna, Kenneth J., Jamie Seeholzer, and Joseph Salem Jr. "No Natives Here: a Focus Group Study of Student Perceptions of Web 2.0 and the Academic Library.” Journal of Academic Librarianship 35.6 (2009): 523-532. Print.

Christiansen, Lars, Mindy Stombler, and Lyn Thaxton. "A Report on Library-Faculty Relations From a Sociological Perspective.” Journal of Academic Librarianship 30.2 (2004): 116-121. Print.

“CILIP Comes Out Fighting on Cuts.” Library \& Information Update 6.9 (2007): 2. Print.

Corrall, Sheila. "Rethinking Professional Competence For the Networked Environment." Developing Academic Library Staff for Future Success. Ed. Margaret Oldroyd. London: Facet, 2004. 15-39.Print.

Crawford, Alice. “Academic Liaison Librarians - Where Do We Stand?” SCONUL Focus 45 (2009): 34. Print and Web.

Cummings, Lara Ursin. "Bursting Out of the Box: Outreach to the Millennial Generation Through Student Services Programs.” Reference Services Review 35.2 (2007): 28595. Print.

Curtis, Polly. "Bangor Librarians Face Internet Threat.” The Guardian 16 Feb. 2005. Web. 5 Aug. 2010.

Dilevko, Juris. “An Ideological Analysis of Digital Reference Service Models.” Library Trends 50.2 (2001): 218 - 44. Print.

Doskatsch, Irene. "Perceptions and Perplexities of the Faculty-Librarian Partnership: an Australian Perspective.” Reference Services Review 31.2 (2003): 113. Print.

Everest, Katherine and Philip Payne. "The Impact of Libraries on Learning, Teaching and Research: Report of the LIRG Seminar Held in Leeds, 30 ${ }^{\text {th }}$ October 2001.” Library and Information Research 25.81 (2001): 18-22. Print and Web.

Feetham, Margaret. "The Subject Specialist in Higher Education - a Review of the Literature.” Subject Librarians: Engaging With the Learning and Teaching Environment. Ed. Penny Dale, Matt Holland and Marian Matthews. Aldershot: Ashgate, 2006. 3-17. Print.

Gannon-Leary, Pat, Moira Bent, and Jo Webb. “A Destination Or Place of Last Resort? The Research Library of the Future, Its Users and Its Librarians.” Library and Information Research 32.101 (2008): 3-14. Web. 10 Aug. 2010.

Gibbons, Susan. The Academic Library and the Net Gen Student. Chicago: American Library Association, 2007. Print.

Gibson, Suzanne and Julie Luxton. "Departure From the Library Desk! One Undergraduate Programme’s Story of its Subject Librarian’s Evolving Role.” SCONUL Focus 45 (2009): 41 - 44. Print. 
Glynn, Tom and Connie Wu. "New Roles and Opportunities For Academic Library Liaisons: a Survey and Recommendations.” Reference Services Review 31.2 (2003): 122-128. Print.

Higher Education Funding Council for England. HEFCE Equality Scheme. Jan. 2007. Web. 27 July 2010.

Holbrook, Anthony. "The Subject Librarian and Social Scientists: Liaison In a University Setting.” Aslib Proceedings 36.6 (1984): 269-275. Print.

Hutchings, C. 2009. "Impact of the Economic Downturn on University Library and IT Services.” JISC Briefing Paper. Sept. 2009. Web. 5 Nov. 2009.

Kotter, Wade R. " Bridging the Great Divide: Improving Relations Between Librarians and Classroom Faculty.” Journal of Academic Librarianship 25.4 (1999): 294-303. Print.

Levy, Phillipa and Sue Roberts. Developing the New Learning Environment: the Changing Role of the Academic Librarian. London: Facet, 2005. Print.

Lewis, Ben. "Widening Participation In Higher Education: the HEFCE Perspective On Policy and Progress.” Higher Education Quarterly 56.2 (2002): 204-219. Print.

Lindauer, Bonnie Gratch. “ Defining and Measuring the Library's Impact On Campus-Wide Outcomes.” College and Research Libraries 59.6 (1998): 546-570. Print.

Lund, Peter, Graham Walton and Helen Young. Use of University Library by Research Centres. Loughborough: Loughborough University Library, February 2009. Web. 10 Aug. 2010.

Markless, Sharon and David Streatfield. "Gathering and Applying Evidence of the Impact of UK University Libraries On Student Learning and Research: a Facilitated Action Research Approach.” International Journal of Information Management 26.1 (2006): 3-15. Print.

McAbee, Sonja L. and John-Bauer Graham. "Expectations, Realities and Perceptions of Subject Specialist Librarians’ Duties In Medium-Sized Academic Libraries.” Journal of Academic Librarianship 31.1 (2005): 25. Print.

McGuiness, Claire. "Attitudes of Academics To the Library’s Role In Information Literacy Education.” Information and IT Literacy: Enabling Learning In the 21st Century. Ed. Allan Martin and Hannelore Rader. London: Facet, 2003. 244-54. Print.

Mi, Jia and Frederick Nesta, F. “ Marketing Library Services To the Net Generation.” Library Management 27.6/7 (2006): 411-422. Print.

Morgan, Steve. "Developing Academic Library Skills for the Future”. Library Review 45.5 (1996): 41-53. Print.

Neal, Clifford, Heather Parsonage and Heather Shaw. "It's All Up For Grabs: Developing a New Role For the Academic Liaison Team At NTU.” SCONUL Focus 45 (2009): 4-8. Print.

Pinfield, Stephen. “The Changing Role of Subject Librarians In Academic Libraries.” Journal of Librarianship and Information Science 33.1 (2001): 32-8. Print.

Poll, Roswitha and Philip Payne. "Impact Measures For Libraries And Information Services." Library Hi Tech 24.4 (2006): 547-562. Print.

Prensky, Marc. “Digital Natives, Digital Immigrants.” On the Horizon 9.5 (2001): n.pag. Web. 26 July 2010.

Reisz, Matthew. “'Wow’ Students To Maintain the Library’s Central Position.” Times Higher Education 31 December 2009: 16. Print.

Research Information Network and Consortium of Research Libraries. Researchers' Use of Academic Libraries And Their Services. London: RIN, 2007. Web. 12 Aug. 2010.

Richardson, Hannah. “ University Budget Cuts Revealed.” BBC News Channel. 1 Feb. 2010. Web. 26 July 2010. 
Rodwell, John and Linden Fairbairn. "Dangerous Liaisons?: Defining the Faculty Liaison Librarian Service Model, Its Effectiveness and Sustainability.” Library Management 29.1/2 (2008): 116 - 124. Print.

Ryans, Cynthia C., Suresh, RaghiniS., and Zhang, Wei-Ping. “Assessing an Academic Library Liaison Programme.” Library Review 44.1 (1995): 14-23. Print.

Selwyn, Neil. “The Digital Native - Myth and Reality.” Aslib Proceedings 61.4 (2009): 364379. Print.

Sturges, Paul. “Gatekeepers and Other Intermediaries.” Aslib Proceedings 53.2 (2001): 6267. Print.

Webber, Sheila, Boon, Stuart, and Johnston, Bill. “A Comparison of UK Academics' Conceptions of Information Literacy in Two Disciplines: English and Marketing”. Library and Information Research 29.93 (2005): 4-15.

Yang, ZhenYe. "University Faculty's Perception of a Library Liaison Program: a Case Study.” Journal of Academic Librarianship 26.2 (2000): 124-128. Print. 